\title{
School Climate and Self-Efficacy as Predictor of Job Satisfaction
}

\section{İş Doyumunun Yordayıcısı Olarak Okul İklimi ve Öz-Yeterlik}

\author{
Yusuf TÜRKER* (iD) Ümit KAHRAMAN**
}

\begin{abstract}
Received: 22 March 2021
Research Article

Accepted: 27 July 2021

ABSTRACT: In this research, the direct effect of school climate on teacher job satisfaction and the indirect effect of school climate on job satisfaction through self-efficacy were investigated. International Teaching and Learning Survey-2018 data collected by the Organization for Economic Co-operation and Development from Turkish teachers were used in the study. The research data were obtained from the responses of the participants to the Teacher SelfEfficacy, Job Satisfaction and School Climate scales in the International Teaching and Learning Research Teacher Questionnaire. Although a total of 15498 teachers working in primary school, lower secondary school and upper secondary school participated in the research, participants with missing data were excluded from the analysis. Within the scope of the research, data obtained from 12111 teachers were used. Following the testing of the constructed model with the structural equation model, the following results were obtained: Teachers' self-efficacy directly affects job satisfaction. The perceived disciplinary dimension of the school climate directly and negatively affects job satisfaction. The other two dimensions of the school climate, teacher-student relations and the dimensions of participation among stakeholders, affect job satisfaction directly and positively. All dimensions of the school climate indirectly affect job satisfaction through self-efficacy.
\end{abstract}

Keywords: School climate, self-efficacy, job satisfaction, TALIS 2018.

ÖZ: Bu çalışmada, algılanan okul ikliminin öğretmen iş doyumunu nasıl etkilediği ve öz yeterliliğin okul ikliminin iş doyumu üzerindeki etkisinde nasıl aracılık ettiği araştırılmıştır. Araştırmada Ekonomik İş birliği ve Kalkınma Örgütü tarafindan Türk öğretmenlerinden toplanan 2018 Uluslararası Öğretme ve Öğrenme Araştırması verileri kullanılmıştır. Araştırma verileri Uluslararası Öğretme ve Öğrenme Araştırması Öğretmen Anketi'nde yer alan Öğretmen Öz-yeterlik, İş Doyumu ve Okul İklimi ölçeklerine katılımcıların verdikleri yanıtlardan elde edilmiştir. Araştırmaya ilkokul, ortaokul ve lisede görev yapmakta olan toplamda 15498 öğretmen katılmasına rağmen eksik veri içeren katılımcılar analiz dışı bırakılmıştır. Araştırma kapsamında 12111 öğretmenden elde edilen veriler kullanılmıştır. Kurgulanan modelin yapısal eşitlik modeli ile test edilmesinin ardından şu sonuçlara ulaşılmıştır: Öğretmenlerin öz yeterlilikleri iş doyumunu doğrudan etkilemektedir. Okul ikliminin disiplin boyutu iş doyumunu doğrudan ve olumsuz etkilemektedir. Okul ikliminin diğer iki boyutu olan öğretmen öğrenci ilişkileri ve paydaşlar arasında katılım boyutları iş doyumunu doğrudan ve pozitif yönde etkilemektedir. Okul ikliminin bütün boyutları öz yeterlilik üzerinden iş doyumunu dolaylı olarak etkilemektedir.

Anahtar kelimeler: Okul iklimi, özyeterlik, iş doyumu, TALIS 2018.

\footnotetext{
* Dr., Ministry of National Education, Antalya, Turkiye, yusuf.turker@ gmail.com, https://orcid.org/0000-0003-42766648

** Corresponding Author: Asst. Prof. Dr., Bilecik Şeyh Edebali University, Bilecik, Turkiye, drumitkahraman@gmail.com, https://orcid.org/0000-0002-4547-6753
}

Citation Information

Türker, Y., \& Kahraman, Ü. (2021). School climate and self-efficacy as predictor of job satisfaction. Kuramsal Ĕgitimbilim Dergisi [Journal of Theoretical Educational Science], 14(4), 548-569. 
With the discussions of the 4th Industrial Revolution, concepts related to high technology such as the internet of things, artificial intelligence and autonomous systems started to take place on our agenda. The idea that these systems will replace the people in many jobs is a source of fear for some, whereas it is a future they are eagerly waiting for others. The debates also brought about many future predictions on education systems, schools, and the teaching profession. In some of these predictions, it has been claimed that schools will not exist and that teachers will be replaced by various software (Shahroom \& Hussin, 2018; Tanrı̈ğen, 2018). The future world will perhaps justify these views, or it will be proven wrong; perhaps, there will be other consequences that no one has ever predicted. However, it can be suggested that there is no such formation to replace schools and teachers in today's conditions. What happened during COVID-19 pandemic period showed us this once again. The closure of schools around the world due to COVID-19 demonstrated how difficult it is to supply educational necessities of communities without schools and teachers.

Figure 1

Time-Series of School Closure Status from March 2020 to February 2021

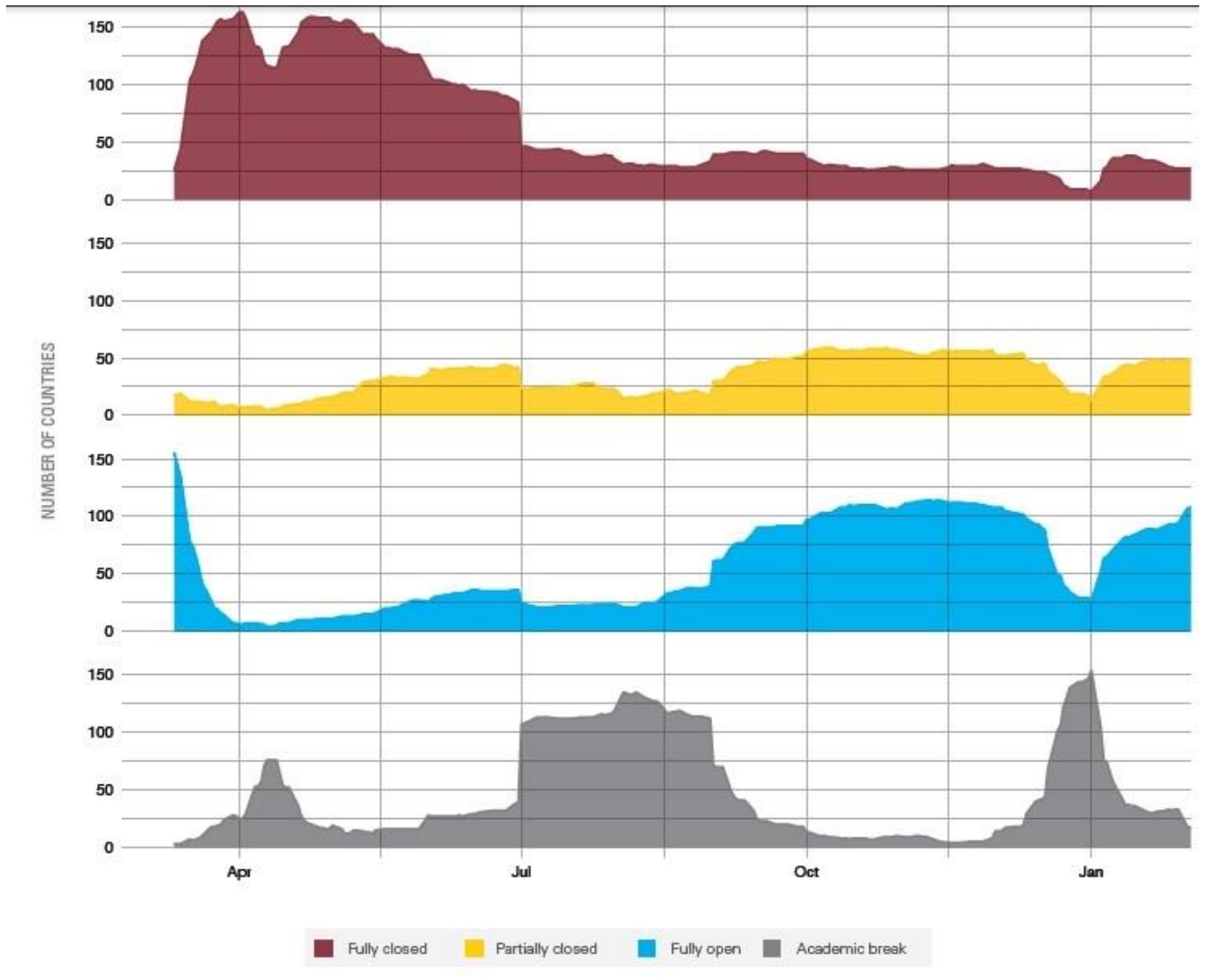

Reference: UNESCO Global monitoring of school closures caused by COVID19 (http://covid19.uis.unesco.org/global-monitoring-school-closures-covid19/)

After the rapid closure observed in the first months of COVID-19, the priority of many countries to keep schools open once again brought up the importance of schools in education systems. When Figure 1 is examined, it is seen that the full closures, which were intensely experienced at the beginning of the pandemic, are gradually decreasing and countries are heading towards full opening (United Nations Educational, Scientific 
and Cultural Organization [UNESCO], 2021a). According to UNESCO data, schools are fully open in 116 countries as of May 31, 2021 (UNESCO, 2021b). Considering that there was an economic recession in the world according to International Monetary Fund data in the same period, it can be said that keeping schools open is more important than maintaining economic activities for some countries (International Monetary Fund [IMF], 2021). In summary, it can be said that schools providing mass education and teachers who provide this education are at an indispensable point in meeting the educational needs of today's societies.

Today the outputs come to the fore when it comes to the effectiveness of education systems. In other words, students' learning is concentrated on. For example, Turkey's results obtained from the Programme for International Student Assessment (PISA) test held by Organization for Economic Co-operation and Development (OECD) are issues discussed by many people. However, as professionals of the education system, teachers' perceptions of the general education system and their professions can be useful for improving effectiveness of education because the improvement of educational outcomes depends on the teacher factor, which is one of the basic inputs of education. In this context, how teachers perceive the education system and the school can be extremely useful in terms of self-evaluation of themselves, determining problems, developing solutions, and improving human resources.

While OECD focuses on the student dimension of education systems with PISA exam, Teaching and Learning International Survey (TALIS) focuses on school administrators and teachers. TALIS aims to examine the effects of educational policies implemented by governments in schools in terms of teachers and school principals. In the TALIS research, which was implemented for the third time in 2018 by the OECD participated by 48 countries and economies, the participants were asked various questions about teachers' professional experience and qualifications, professional development, teaching practices, job satisfaction, perceptions of cultural diversity, school climate, and their own competence levels. Although OECD shares its reports containing country-based and inter-country comparisons with the international community, these reports do not include in-depth analysis. The organization shares the data it obtains and makes it available to researchers who ask for access. TALIS (performed by the OECD in 2018) data was used in this article. The data used in the study are obtained from teachers in Turkey. The research focuses on the variables of school climate, self-efficacy and job satisfaction. In this context, our problem is whether self-efficacy has a mediating role in the effect of school climate on job satisfaction.

\section{Theoretical Framework}

\section{School Climate}

Although the first researches on school climate started in the 1950s (Cohen et al., 2009), it cannot be said that the concept has an agreed definition yet (Malinen \& Savolainen, 2016). According to many researchers, the school climate occurs of common values, faiths and opinions. These common values, faiths, and opinions shape school stakeholders' interactions and determine the characteristics of behavior and norms (Emmons et al., 1996; Esposito, 1999; Mitchell et al., 2010). There are also those who try to explain the school climate in more abstract terms. The school climate is the 
core and spirit that shapes the mood of stakeholders. This mood may cause students, teachers and administrators to be willing or unwilling to come to school (Freiberg \& Stein, 1999).

The school climate shapes the interactions of all school stakeholders, namely students, teachers, administrators, other staff of the school and parents. This shaping creates the school's goals, norms and values. The school realizes its educational and social functions through these created goals, values and norms. The fact that the school has social functions, as well as educational functions, reveals that the school is not just an educational institution. According to Cohen et al. (2009), a school is a place where students experience meaningful social relationships and being able to act independently. With this aspect, school is not only a place where students develop cognitively but also an environment where they develop emotionally and behaviorally. Although there are many definitions of school climate, we chose a teacher-centered definition. Johnson et al. (2007) define the school climate in teacher-oriented perspective. School climate is a psychosocial environment where teachers instruct and teach. The school climate is analyzed from this perspective in the study.

Researches appear that school climate is related to many variables associated to education. While positive perceptions about school climate reduce the stress, wear and burnout of teachers; It positively affects teachers' perceptions of self-efficacy, job satisfaction and their relations with students (Collie et al., 2012; Lee \& Louis, 2019; Lee et al., 1991; Van Beurden et al., 2017). The positive school climate also increases teachers' possibility of remaining in the profession (Ingersoll, 2001). The school climate is not only effective on teacher outcomes. While positive school climate perception increases students' academic achievement and learning will, it also decreases aggression and the possibility of taking a break from school (Cohen et al., 2009; Thapa et al., 2013).

\section{Self-Efficacy}

According to Bandura (1997), although individuals have control over their behavior, behavior and consciousness are affected by environmental factors. According to him, the perception of self-efficacy created by consciousness shapes the goals and actions of the person on the one hand and is also affected by environmental conditions. Self-efficacy expresses the belief in designing the actions that lead to the goal with one aspect and realizing them in the other. These beliefs about self-efficacy are not static personality traits, and they can be learned. These beliefs can change according to how the person perceives their environment (Bandura, 1997).

When self-efficacy is evaluated from the teacher's perspective, it can be defined as the teacher's belief to be effective on student outcomes (Tschannen-Moran et al., 1998). According to Dellinger et al. (2008), self-efficacy is the teachers' personal faiths that he/she can perform the defined teaching missions under certain environmental conditions. Teachers' perception of self-efficacy cannot be considered only as teachers' personal beliefs about themselves. Teachers' self-efficacy faiths can affect children's behavior, learning and self-efficacy. Having a powerful sensation of self-efficacy, teacher can increase student participation by making teaching activities more meaningful for everyone. According to Gibson and Dembo (1984), teachers with strong 
self-efficacy have confidence that they can influence and teach even the most problematic students.

Studies reveal that teachers' self-efficacy is effective on students' output. Hattie (2003) observed that teacher self-efficacy affects students' learning more than teacher effectiveness. Many researches have revealed that teacher self-efficacy positively affects students' cognitive achievement (Muijs \& Rejnolds, 2001; Ross, 1998). Teachers who have strong self efficacy may be more innovative and careful about students' autonomy (Cousins \& Walker, 1995). These teachers are willing to get more liability for children who need special education (Allinder, 1994). Teachers with strong self-efficacy perform better in classroom management (Chacon, 2005) and motivate students to learn (Podell \& Soodak, 1993). While students' performance can be affected by teachers' self-efficacy, student performance can also affect teachers' perception of self-efficacy. Raudenbush et al. (1992) found that teachers have strong self-efficacy perception in schools where there are successful students.

Teacher self-efficacy is associated with many organizational variables-a negative correlation between teachers' self-efficacy with stress and burnout found by Betoret (2009). Caprara et al. (2003, 2006) showed that self-efficacy is positively associated with job satisfaction. There is a correlation between school climate and selfefficacy. Teachers' self-efficacy perceptions can rise when school climate is positive (Ciani et al., 2008). Additionally, high teacher self-efficacy decreases tendency of leave the profession (Soodak \& Podell, 1993).

Self-efficacy perception is not a feature that becomes stable once it is acquired. Environmental conditions can affect self-efficacy perception (Bandura, 2012). Teachers' perception of self-efficacy is relative and may change according to environmental conditions (Gibson \& Dembo, 1984). Hoy and Woolfolk (1993) also support the view that self-efficacy perception is relative and argue that it will be affected by the school climate. Findings from previous studies also reveal that selfefficacy perception is not a fixed variable. While the perception of self-efficacy is affected by other variables, on the one hand, it may affect different variables on the other hand. For this respect, we assume that teacher self-efficacy can be affected by school climate and can influence job satisfaction. With another expression, self-efficacy can play a mediator role in relation to school climate with job satisfaction.

\section{Job Satisfaction}

Job satisfaction is a sum of people's positive or negative feelings concerning their professions (Locke, 1976). On the other hand, teacher job satisfaction can be defined as the sense of satisfaction that people have with the teaching profession (Ainley \& Carstens, 2018). According to Skaalvik and Skaalvik (2015), teacher job satisfaction is the sum of positive and negative evaluations of teachers about their profession.

Researches show that teacher job satisfaction is correlated with many organizational and educational variables. While the increase in teacher job satisfaction increases performance (Judge et al., 2001), perception of self-efficacy (Caprara et al., 2003) and commitment (Reyes \& Shin, 1995); It has been detected to reduce burnout (Skaalvik \& Skaalvik, 2010) and stress (Klassen et al., 2010). In addition, it has been found that job satisfaction is positively interrelated with enthusiasm (Chen, 2007), 
teacher-student relations (Dinham, 1995), and relationships with parents (Skaalvik \& Skaalvik, 2011). Some researchers argue that job satisfaction is a strong indicator of teachers' tendency to stay or quit the profession (McConnell, 2017; Schaufeli \& Salanova, 2007).

Job satisfaction means the level of contentment teachers achieve from their profession after evaluating positive or negative professional experiences as a whole. With this aspect, job satisfaction can be evaluated as a result affected by different variables. It has been observed in other studies that the variables of school climate and self-efficacy considered in the research are effective on job satisfaction. Having positive views on school climate positively affects teachers' job satisfaction perceptions (Collie et al., 2012; Lee et al., 1991; Veldman et al., 2013). Similarly, researchers have manifested a positive relationship between self-efficacy and job satisfaction (Caprara et al., 2003, 2006; Skaalvik \& Skaalvik, 2009, 2014). The former research results have led us to think that school climate and self-efficacy may affect teachers' job satisfaction.

\section{Method}

This research, which aims to determine relationships between school climate, self-efficacy, and job satisfaction, is correlational. The study utilized structural equation modeling (SEM) analysis to examine school climate's direct effect on job satisfaction and indirect effect through self-efficacy. School climate is independent, self-efficacy is mediating, and job satisfaction is dependent variable in the constructional model.

Figure 2

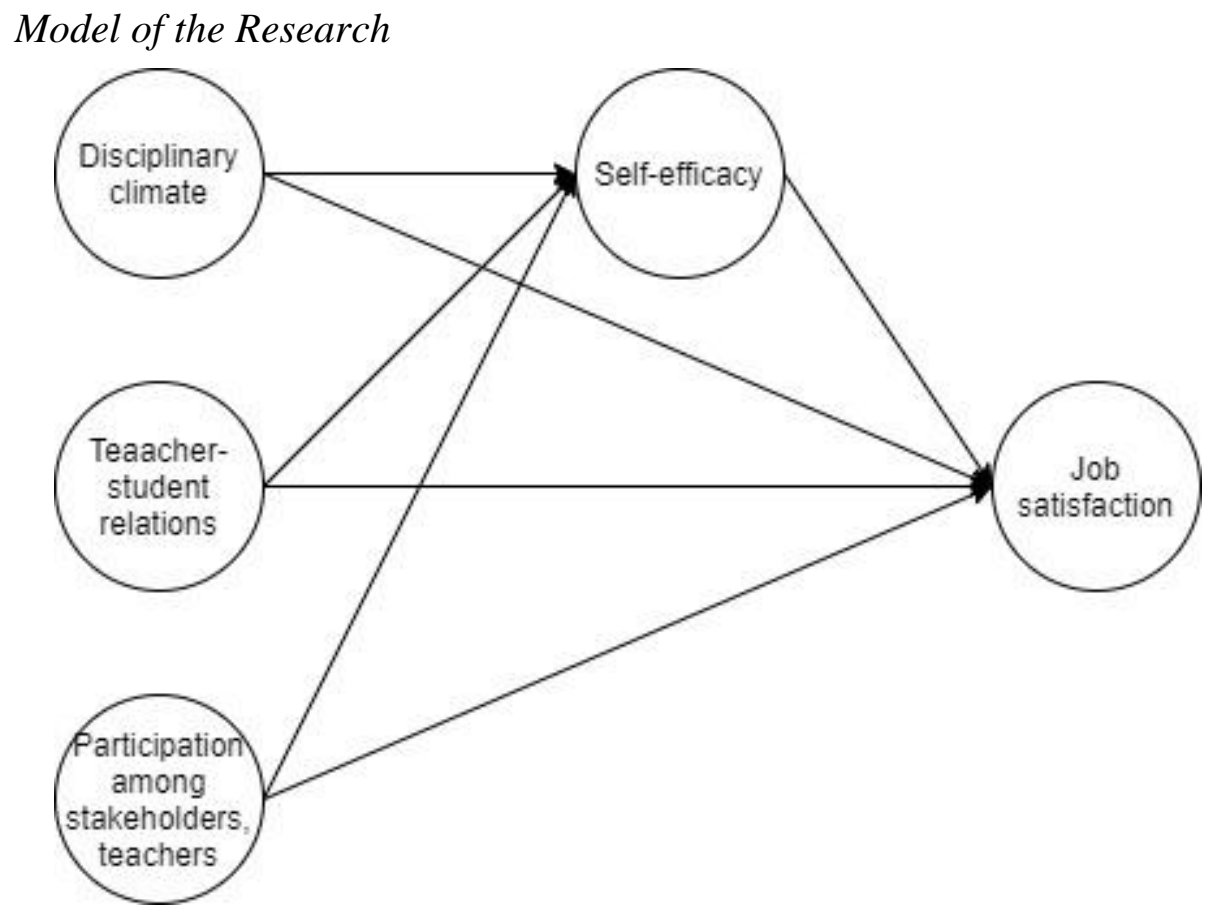

According to Figure 2, the effects of 'teachers' perceived disciplinary, Teacherstudent relations and participation among stakeholders", which are the subscales of the school climate, are independent variables. The reason why the subscales of the school climate are evaluated separately is that the scale is not able to get the total score and the 
discipline subscale is aimed to measure a negative aspect of the school climate since it contains negative expressions.

\section{Participants and Procedures}

In the research, we used the TALIS (2018) data concluded by the OECD. The OECD shares this data on its official website (https://www.oecd.org/education/talis/talis-2018-data.htm). TALIS 2018 consists of the data collected from school principals and teachers from 48 countries, including Turkey. School levels in TALIS are named according to UNESCO classification. According to the UNESCO classification, the International Standard Classification of Education is expressed by the abbreviation ISCED. In TALIS, ISCED Level 1 refers to primary schools, ISCED Level 2 refers to secondary schools, and ISCED Level 3 refers to upper secondary schools. The participants from Turkey consisted of 171 school principals and 3204 teachers from 172 primary schools (ISCED Level 1); 196 school principals and 3952 teachers from 196 secondary schools (ISCED Level 2); and 448 principals and 8342 teachers from 457 upper secondary schools (ISCED Level 3) (OECD, 2019; UNESCO-UIS, 2012).

Only the data collected from teachers were used in this study. Since the data obtained from the OECD database are raw data, some adjustments have been made. For this purpose, the data of the participants containing missing data were excluded from the analysis. Within the scope of the research, we used the data obtained from a total of 12111 teachers, including 2461 from primary schools (20.3\%), 3056 from secondary schools (25.2\%), and 6594 from upper secondary schools (54.4\%). 53\% (6416) of those participating in the study are women and 47\% (5695) of them are men.

\section{Data Collection Tools}

The data used in the research were obtained from three different measurement tools. The "School Climate Scale", the first of these scales, consists of three subscales and 13 items (See Appendix 1). Scale items are four-point Likert type, and response options are "strongly disagree", "disagree", "agree" and "strongly agree" (OECD, 2019). After reliability analysis, we found .84 Cronbach alpha value for teachers' perceived disciplinary dimension, .86 for teacher-student relations and .92 for participation among stakeholders dimension.

Another measurement tool used in the research is the "Teacher Self-Efficacy Scale". The assessment tool consists of three subscales and 12 dimensions (See Appendix 2). The scale is in the four-point Likert type and the response options are "none", "to some degree", "a little" and "a lot" (OECD, 2019). After reliability re-made reliability analysis of the scale, Cronbach alpha value was found as .84 for self-efficacy in classroom management, .81 for self-efficacy in instruction, .84 for self-efficacy in student engagement, and .91 for the overall scale.

The last scale used in the research is Job Satisfaction Scale. The measurement tool consists of three dimensions and 13 items (See Appendix 3). The scale items are four-point Likert type ranging from "strongly disagree" to "strongly agree" (OECD, 2019). As a result of the re-made reliability analysis of the scale, the Cronbach alpha value was found as .79 for job satisfaction in the work environment, .79 for job 
satisfaction with the profession, .86 for satisfaction with target class autonomy, and .82 for the overall scale.

Table 1

Reliability Coefficients of Measurement Tools Calculated by OECD

\begin{tabular}{|c|c|c|c|c|}
\hline \multicolumn{2}{|c|}{ Variable } & ISCED & ISCED & ISCED \\
\hline \multirow{3}{*}{ 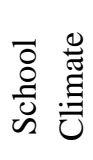 } & Teachers' perceived disciplinary & .89 & .90 & .90 \\
\hline & Teacher-student relations & .91 & .88 & .88 \\
\hline & Participation among stakeholders, teachers & .91 & .90 & .90 \\
\hline \multirow{4}{*}{ 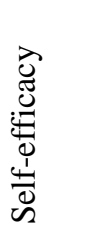 } & Self-efficacy in classroom management & .86 & .88 & .86 \\
\hline & Self-efficacy in instruction & .85 & .82 & .82 \\
\hline & Self-efficacy in student engagement & .82 & .81 & .79 \\
\hline & Total self-efficacy & .93 & .93 & .92 \\
\hline \multirow{4}{*}{ 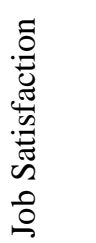 } & Job satisfaction with work environment & .85 & .86 & .85 \\
\hline & Job satisfaction with profession & .84 & .86 & .85 \\
\hline & Satisfaction with target class autonomy & .89 & .90 & .88 \\
\hline & Total job satisfaction & .89 & .89 & .89 \\
\hline
\end{tabular}

\section{Data Analysis}

Two analyses were made in the study. The first one is about testing the reliability of measurement instruments in terms of the data obtained from the Turkey sample. SPSS Statistics 17.0 program was used at this stage. In the second analysis, structural equation modelling (SEM), the AMOS 16 package program was used. Whether the data is distributed normally is a basic criterion in the confirmatory factor analysis (Bayram, 2016). Within the scope of the structural equation model analysis, a theory-based model has been constructed to test the relationship between variables. There are different opinions about which fit indices to use. According to Kline (2011), it is sufficient to report chi-square, RMSEA, CFI and SRMR. Jackson et al. (2009) stated that the most frequently reported fit indices in SEM studies were chi-square and degrees of freedom, CFI, RMSEA, and TLI. However, Brown (2014) states that using the chisquare statistic to evaluate the goodness of fit in studies with a large sample size can be misleading because this value is very sensitive to the sample size. In our research, the chi-square statistic was not employed to evaluate goodness of fit since it was a large sample group consisting of 12111 participants. So, we decided to report RMSEA, CFI, TLI and SRMR fit indices. While values of .08 for RMSEA and .06 and below for SRMR are accepted; values of .90 and above were accepted for other goodness of fit criteria (Hu \& Bentler, 1999; Karagöz, 2016).

In order to use multivariate statistical techniques, it is necessary to provide the assumption of multivariate normality. Multivariate normality means that the observations in the sample are normally distributed for all combinations of variables. Also, for multivariate normality, each variable must meet the univariate normality assumption. However, meeting the univariate normality assumption does not guarantee 
that the multivariate normality assumption will be met (Çokluk et al., 2012; Mertler \& Vannatta, 2005, cited in Akar, 2017). Skewness and kurtosis coefficients were used to examine univariate normality. The skewness and kurtosis coefficients of the measurement instruments vary between .065 and 1.605. The fact that the values obtained are within the acceptable limits in the literature indicates that the data are normally distributed (George \& Mallery, 2010; Karagöz, 2016). To examine multivariate normality, Mardia's multivariate normality coefficient and critical ratio (c.r.) values were examined. It can be said that multiple normality is not achieved when the critical ratio value is greater than 5 (Yuan et al., 2005) and the Mardia coefficient is greater than 1.96 (Bayram, 2016). In the study, the Mardia coefficient was found to be 370,364 and the critical ratio value was 369,617 . Since the data do not support the multiple normality assumption, a Bootstrap analysis was performed where the normal distribution was not required (Bayram, 2016).

Multicollinearity is another assumption of structural equation modeling. The results of the correlation analysis performed to understand whether there is multicollinearity between the variables are given in Table 2 .

Table 2

Correlation Values between Variables

\begin{tabular}{lccccc}
\hline Variables & $\begin{array}{c}\text { Job } \\
\text { Satisfaction }\end{array}$ & $\begin{array}{c}\text { Self- } \\
\text { efficacy }\end{array}$ & $\begin{array}{c}\text { Teachers' } \\
\text { perceived } \\
\text { disciplinary }\end{array}$ & $\begin{array}{c}\text { Teacher- } \\
\text { student } \\
\text { relations }\end{array}$ & $\begin{array}{c}\text { Participation } \\
\text { among } \\
\text { stakeholder }\end{array}$ \\
\hline Job Satisfaction & 1 & & & \\
Self-efficacy & $342^{* *}$ & 1 & & \\
Teachers' perceived disciplinary & $-.356^{* *}$ & $-.273^{* *}$ & 1 & 1 \\
Teacher-student relations & $.417^{* *}$ & $.314^{* *}$ & $-.230^{* *}$ & 1 \\
Participation among stakeholder & $.407 * *$ & $.220^{* *}$ & $-.169 * *$ & $.537 * *$ & 1 \\
\hline
\end{tabular}

**Correlation is significant at the .01 level (2-tailed).

When Table 2 is examined, the fact that the values of the correlation between the variables are below .80 can be interpreted as the absence of a multicollinearity problem (Büyüköztürk, 2006). After the normality and multicollinearity analyses, the measurement model, which is a confirmatory factor analysis (Bollen, 1989, cited in Akar, 2017) for the structural model, was tested. The fit index values obtained for the measurement model $(\mathrm{CFI}=.918, \mathrm{TLI}=.912, \mathrm{RMSEA}=.052, \mathrm{SRMR}=.058)$ show that the model was confirmed.

\section{Limitations}

We used the data obtained from teachers in the research and excluded the school principals from the scope of the research. Further studies that may include analyses including school principals may allow comparisons and an overall generalization. Although TALIS 2018 data were collected from 48 countries and economies, the results were obtained from the Turkey sampling. If the scope of research can be adjusted 
comprehensively enough to cover more countries, it may be useful in revealing the similarities and differences between cultures.

\section{Ethical Procedures}

Ethical board approval is not required as OECD data are used in this study.

\section{Results}

SEM tests whether the available data support a structure that is thought to exist. In this respect, in SEM, the model should be designed first and then the model should be tested whether it is verified with data. The path coefficients regarding the significance of the relationships in the model designed to test the direct effects of school climate on job satisfaction and its indirect effects through self-efficacy are given in Table 3.

Table 3

Model Path Coefficients

\begin{tabular}{lccccc}
\hline Relationships Between Variables & $B$ & $\beta$ & $S . E$. & $C . R .(t)$ & $p$ \\
\hline Self-efficacy <--- Teachers' perceived disciplinary & -.134 & -.221 & .006 & -21.72 & $* * *$ \\
Job Satisfaction<--- Teachers' perceived disciplinary & -.180 & -.273 & .007 & -24.23 & $* * *$ \\
Self-efficacy <--- Teacher-student relations & .272 & .275 & .013 & 21.350 & $* * *$ \\
Job Satisfaction<--- Teacher-student relations & .232 & .217 & .015 & 15.785 & $* * *$ \\
Self-efficacy <--- Participation among stakeholders & .038 & .056 & .008 & 4.708 & $* * *$ \\
Job Satisfaction<--- Participation among stakeholder & .337 & .465 & .010 & 33.692 & $* * *$ \\
Job Satisfaction<--- Self-efficacy & .142 & .131 & .013 & 11.241 & $* * *$ \\
\hline
\end{tabular}

The path coefficients are expected to be significant in order for the model whose accuracy is tested in SEM to be valid. C.R. (t) value is checked for the significance of the path coefficients. If this value exceeds 1.96, it points out a level of significance at 0.05 , and if it exceeds 2.56, it means there is a level of significance at 0.01 (Çokluk et al., 2014; Tabachnick \& Fidel, 2001). Looking at Table 2, it is seen that all path coefficients in the model are significant. The second stage followed in the analysis of the model is related to the values of fit index. For the model to be acceptable, fit index values must be within the acceptance range (Byrne, 2010; Kline, 2011). Fit index values of the model were calculated as CFI=.918, TLI=.912, RMSEA=.052, SRMR=.058. These values are sufficient for the model to be acceptable (Hu \& Bentler, 1999; Karagöz, 2016). It can be suggested that the model constructed with the path coefficients and fit index values obtained from SEM result is confirmed with the data obtained from the sample group. The model verified with fit index values is given in Figure 3. 
Figure 3

Mediating Effect of Self-Efficacy in the Relationship between School Climate and Job Satisfaction

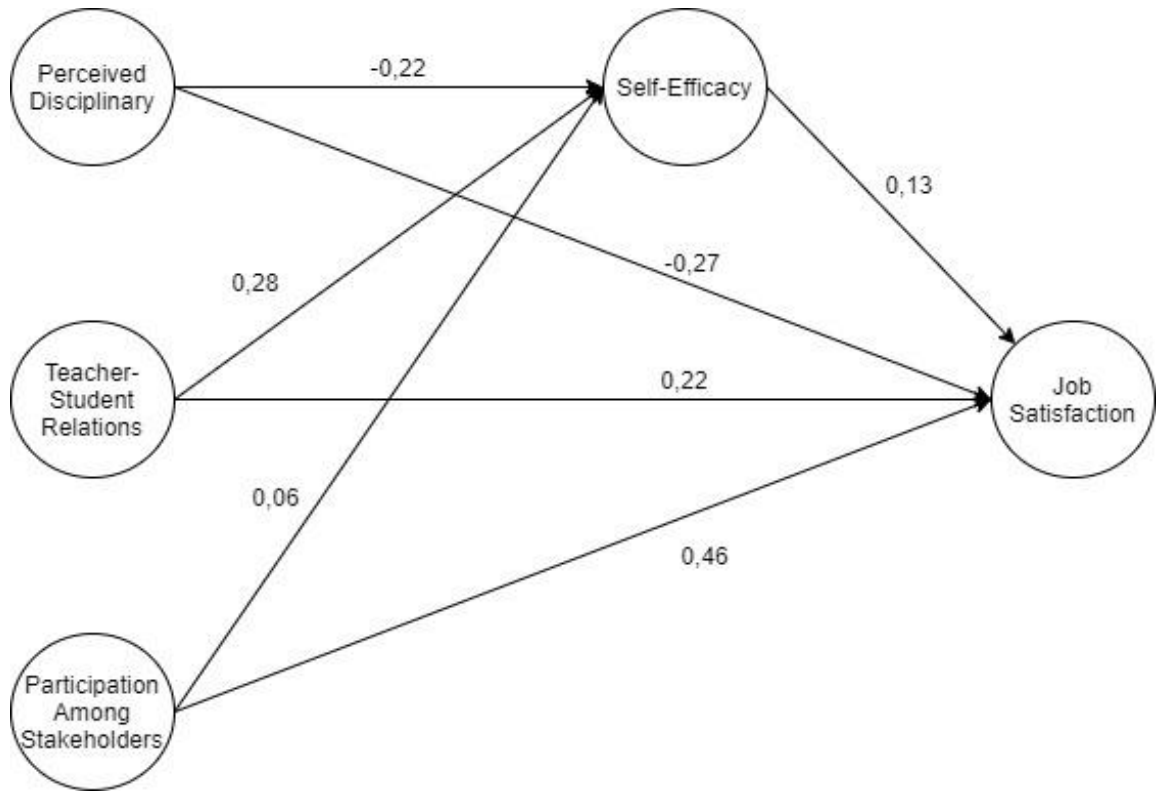

Figure 3 illustrates that all dimensions of school climate directly affect job satisfaction. The indirect effects of school climate on job satisfaction through selfefficacy were calculated using the bootstrapping method. Teachers' perceived disciplinary dimension of the school climate has an indirect effect on job satisfaction. The standardized coefficient for indirect effect was calculated as 0.010 (indirect effect [$0.034,-0.023$ ] for $95 \%$ confidence interval). Teacher-student relationships also have an indirect effect on job satisfaction. The standardized coefficient for indirect effect was calculated as 0.010 (indirect effect $[0.029,0.043]$ for $95 \%$ confidence interval). The dimension of participation among stakeholders was found to affect job satisfaction indirectly. The standardized coefficient for indirect effect was calculated as 0.010 (indirect effect [0.005-0.011] for 95\% confidence interval). The dimensions of the school climate and the perception of self-efficacy account for $61 \%$ of the variance in teacher job satisfaction. The dimensions of school climate also account for $18 \%$ of the variance in self-efficacy perception. Standardized effects showing direct and indirect effects in the model are given in Table 4.

Table 4

Standardized Effects of the Mediating Model

\begin{tabular}{lccc}
\hline Relationships Between Variables & Direct effect & Indirect effect & Total effect \\
\hline Self-efficacy $\quad<---$ Teachers' perceived disciplinary & -.221 & --- & -.221 \\
Job Satisfaction<--- Teachers' perceived disciplinary & -.273 & -.029 & -.302 \\
Self-efficacy <--- Teacher-student relations & .275 & --- & .275 \\
Job Satisfaction<--- Teacher-student relations & .217 & .036 & .254 \\
Self-efficacy <--- Participation among stakeholders & .056 & --- & .056 \\
Job Satisfaction<--- Participation among stakeholder & .465 & .007 & .472 \\
Job Satisfaction<--- Self-efficacy & .131 & ---- & .131 \\
\hline
\end{tabular}


Given the standardized path coefficients in Table 4, it is seen that the dimensions of teachers' perceived disciplinary, teacher-student relations and participation among stakeholders belonging to the school climate variable have direct and indirect effects on job satisfaction. Regarding the direct effects, a one-unit increase in the perception of discipline causes a -.221 decrease in the perception of self-efficacy and a -.273 unit decrease in the perception of job satisfaction. One-unit increase in the perception of teacher-student relationships increases the perception of self-efficacy at .275 level and job satisfaction at .217 level. One unit increase in the perception of participation can create a change of .056 units in the perception of self-efficacy, while it can create a change of .465 units in the perception of job satisfaction. One-unit increase in selfefficacy causes an increase of .131 units on job satisfaction. When the indirect effects are examined, the effect of the perception of discipline on job satisfaction through selfefficacy was calculated as -.029 , while the total effect was calculated as -.302 . While the indirect effect of teacher-student relationships on job satisfaction through self-efficacy was .036 , the total effect was found to be .254. Finally, while the indirect effect of participation among stakeholders on job satisfaction through self-efficacy was calculated as .007 , the total effect was calculated as .472 .

\section{Discussion and Conclusion}

According to the results revealed self-efficacy directly affects the job satisfaction. While the perceived disciplinary dimension of the school climate directly and negatively affects job satisfaction, the dimensions of teacher-student relations and participation among stakeholders of the school climate directly and positively affect job satisfaction. Finally, all dimensions of school climate also indirectly affect job satisfaction through self-efficacy.

The result that the perception of self-efficacy has a direct and positive effect on job satisfaction, found in this research, is parallel to the results of the study conducted by Zakariya (2020). Zakariya (2020) used TALIS 2018 data of the Norwegian middle school teachers in his research and found that self-efficacy directly affects job satisfaction. Likewise, Katsantonis (2020) concluded that self-efficacy has a direct effect on job satisfaction due to the research using TALIS 2018 data obtained from primary school teachers from 15 countries, including Turkey. Malinen and Savolainen (2016) also detected that teachers' self-efficacy directly affects job satisfaction. In her meta-analysis of 35 studies, Kalkan (2020) concluded that the general effect size of the relationship between teachers' self-efficacy beliefs and job satisfaction levels is positive and moderate. When the literature is examined, it is possible to reach the results of many domestic and foreign pieces of research on the effect of self-efficacy on job satisfaction (Aldridge \& Fraser, 2016; Caprara et al., 2003, 2006; Edinger \& Edinger, 2018; Köksal, 2019; Ruma et al., 2010; Seyhan, 2015; Skaalvik \& Skaalvik, 2014; Telef, 2011; Turcan, 2011; You et al., 2017)

The conclusion that the perceived disciplinary dimension of the school climate has a direct and negative effect on job satisfaction is similar to the studies of Zakariya (2020) and Katsantonis (2020). The negative impact of the perception of discipline should be evaluated considering that the items that make up this dimension of the measuring tool contain negative statements. In schools and classrooms where the implementation of the rules is problematic, teachers' job satisfaction is negatively 
affected by the increased effort and time they spend to provide discipline. It is also possible to see similar results in OECD's 2013 TALIS research. It has been reported that countries and economies where students with behavioral problems have a higher percentage have lower job satisfaction among teachers (OECD, 2014).

The teacher-student relations dimension and participation among stakeholders dimension of the school climate also have a direct effect on job satisfaction. This effect is not negative as found in the perceived disciplinary dimension but positive. The result that school climate has an effect on job satisfaction supports the study of Polat (2018), in which she found significant positive relationships between job satisfaction level and organizational climate. The result obtained also shows parallelism with Mert and Özdemir's (2019) study, which found a moderately positive relationship between teachers' job satisfaction and psychological climate. It is also possible to come across other research results suggesting that school climate directly affects job satisfaction (Aldridge \& Fraser, 2016; Katsantonis, 2020; Malinen \& Savolainen, 2016; Zakariya, 2020). Studies in which sample groups are from different countries show that positive perceptions of school climate and student behavior positively affect teacher job satisfaction. OECD's (2014) 2013 TALIS study reveals that the indicators of school climate predict job satisfaction

The perceived disciplinary dimension of the school climate negatively affects job satisfaction through self-efficacy. There are studies supporting this result. Raudenbush et al. (1992) point to a reciprocal effect between the perceived self-efficacy of the teacher and the student's achievement. Teachers' perceptions of self-efficacy are also high in schools with successful and good-natured students. For this reason, the high number of students with behavioral problems may negatively affect teachers' selfefficacy perceptions and job satisfaction. In the studies of Zakariya (2020) and Katsantonis (2020), the perceived disciplinary dimension indirectly affects job satisfaction through self-efficacy.

The dimensions of teacher-student relations and participation among stakeholders of the school climate positively affect job satisfaction through selfefficacy. The finding obtained supports Veldman et al. (2013). Veldman et al. (2013) found that the quality of teacher-student relationship affects teacher job satisfaction. It is also possible to come across other studies on the indirect effect of school climate (Aldridge \& Fraser, 2016; Katsantonis, 2020; Malinen \& Savolainen, 2016; Zakariya, 2020).

According to Bandura (2012), the perception of self-efficacy is affected by the environmental conditions the person is in. Similarly, Gibson and Dembo (1984) pointed out that teacher competence is relative and may not be generalized from one situation to another. With a similar point of view, Hoy and Woolfolk (1993) argued that teachers' sense of competence would be affected by the school climate. In other words, perception of self-efficacy is not a fixed variable; while it is affected by other variables in one aspect, it can affect other variables in the other. For teachers, school climate can create conditions that affect their self-efficacy beliefs, which may affect teacher job satisfaction. The fact that the school climate indirectly affects job satisfaction through self-efficacy, which is a finding obtained from the current study, supports this view. 
The results obtained from this research provide information about the relationships of school climate, self-efficacy and job satisfaction. The dimensions of the school climate have a direct effect on teachers' job satisfaction. In addition to this direct effect, the dimensions of school climate indirectly affect job satisfaction through teacher self-efficacy. Understanding this relationship is highly important in terms of determining effective teachers and sustainability of effectiveness. Some researchers found that teachers' internal evaluations of their work were a strong indicator of staying in the teaching profession and predicted teachers' intention to leave their professions (McConnell, 2017; Schaufeli \& Salanova, 2007). Although leaving the job does not seem like an option in Turkey, where finding a job in general and being employed as a teacher, in particular, is a serious problem, it can be suggested that teachers' internal evaluations of their work will have serious effects on their performance. In order to increase teachers' internal evaluations positively, steps should be taken to strengthen the perceptions of participation among stakeholders and teacher-student relations, which directly and indirectly affect job satisfaction in a positive way. For this purpose, teachers and other school stakeholders' participation in decision-making process can be increased. For teachers to get to know their students better and strengthen their interaction, class sizes and course load can be reduced and consultancy activities can be increased. The current study found that negative student behaviors negatively affect self-efficacy and job satisfaction. Improving teachers' self-efficacy perceptions about their capacity to influence and change unwanted student behavior can counteract this negative effect. It may be beneficial to support teachers with in-service training activities and increase their competencies, especially in schools where many students have behavioral problems.

\section{Statement of Responsibility}

Yusuf Türker; design of research process, data collection, data analysis, writing review and editing. Ümit Kahraman; design of research process, methodology, data analysis, supervision, translate.

\section{Conflicts of Interest}

There are no conflicts of interest in this study. 


\section{References}

Ainley, J., \& Carstens, R. (2018). Teaching and Learning International Survey (TALIS) 2018 conceptual framework, OECD working papers, No. 187. OECD Publishing.

Akar, H. (2017). Öğretmenlerin dönüşümcü liderlik, örgütsel adalet ve örgütsel destek algilarinin iş yaşam kaliteleri üzerine etkisi [Unpublished doctoral dissertation]. İnonü Üniversitesi, Eğitim Bilimleri Enstitüsü.

Aldridge, J. M., \& Fraser, B. J. (2016). Teachers' views of their school climate and its relationship with teacher self-efficacy and job satisfaction. Learning Environments Research, 19(2), 291-307.

Allinder, R. (1994). The relationship between efficacy and the instructional practices of special education teachers and consultants. Teacher Education and Special Education, 17, 86-95.

Bandura, A. (1997). Self-efficacy: The exercise of control. Freeman.

Bandura, A. (2012). On the functional properties of perceived self-efficacy revisited. Journal of Management, 38(1), 9-44. https://doi.org/10.1177/0149206311410606

Bayram, N. (2016). Yapısal eşitlik modellemesine giriş: Amos uygulamaları. Ezgi Kitabevi.

Betoret, F. D. (2009). Self-efficacy, school resources, job stressors and burnout among Spanish primary and secondary school teachers: A structural equation approach. $\begin{array}{llll}\text { Educational } & \text { Psychology, }\end{array}$ https://doi.org/10.1080/01443410802459234

Brown, T. A. (2014). Confirmatory factor analysis for applied research. Guilford Publications.

Büyüköztürk, Ş. (2006). Sosyal bilimler için veri analizi el kitabı. PegemA Yayıncılık.

Byrne, B. M. (2010). Structural equation modeling with AMOS: Basic concepts, applications, and programming (2nd ed.). Taylor and Francis Group.

Caprara, G. V., Barbaranelli, C., Borgogni, L., \& Steca, P. (2003). Efficacy beliefs as determinants of teachers' job satisfaction. Journal of Educational Psychology, 95, 821-832. http://dx.doi.org/10.1037/0022-0663.95.4.821

Caprara, G. V., Barbaranelli, C., Steca, P., \& Malone, P. S. (2006). Teachers' selfefficacy beliefs as determinants of job satisfaction and students' academic achievement: A study at the school level. Journal of School Psychology, 44, 473490. https://doi.org/10.1016/j.jsp.2006.09.001

Chacon, C. T. (2005). Teachers' perceived efficacy among English as a foreign language teacher in middle schools in Venezuela. Teaching and Teacher Education, 21, 257-272. http://dx.doi.org/10.1016/j.tate.2005.01.001

Chen, W. (2007). The structure of secondary school teacher job satisfaction and its relationship with attrition and work enthusiasm. Chinese Education and Society, 40(5), 17-31. https://doi.org/10.2753/CED1061-1932400503

Ciani, K. D., Summers, J., \& Easter, M. A. (2008). A “top-down”, analysis of high school teacher motivation. Contemporary Educational Psychology, 33, 533-560. https://doi.org/10.1016/j.cedpsych.2007.04.002 
Cohen, J., McCabe, L., Michelli, N. M., \& Pickeral, T. (2009). School climate: Research, policy, practice, and teacher education. The Teachers College Record, 111(1), 180-213.

Çokluk, Ö., Şekercioğlu, G., \& Büyüköztürk, Ş. (2014). Sosyal bilimler için çok değişkenli istatistik SPSS ve LISREL uygulamaları. Pegem Yayıncılık.

Collie, R. J., Shapka, J. D., \& Perry, N. E. (2012). School climate and social-emotional learning: Predicting teacher stress, job satisfaction, and teaching efficacy. Journal of Educational Psychology, 104(4), 1189-1204. https://doi.org/10.1037/a0029356

Cousins, J., \& Walker, C. (1995). Personal teacher efficacy as a predictor of teachers' attitudes toward applied educational research. Paper presented at the annual meeting of the Canadian Association for the Study of Educational Administration, Montreal.

Dellinger, A. B., Bobbett, J. J., Olivier, D. F., \& Ellett, C. D. (2008). Measuring teachers' self-efficacy beliefs: Development and use of the TEBS-self. Teaching and Teacher Education, 24(3), 751-766. https://doi.org/10.1016/j.tate.2007.02.010

Dinham, S. (1995). Time to focus on teacher satisfaction. Unicorn, 21(3), 64-75.

Edinger, S. K., \& Edinger, M. J. (2018). Improving teacher job satisfaction: The roles of social capital, teacher efficacy, and support. The Journal of Psychology, 152(8), 573-593. https://doi.org/10.1080/00223980.2018.1489364

Emmons, C. L., Comer, J. P., \& Haynes, N. M. (1996). Translating theory into practice: Comer's theory of school reform. In J. P. Comer, N. M. Haynes, E. Joyner, \& M. Ben-Avie (Eds.), Rallying the whole village (pp. 27-41). Teachers College Press.

Esposito, C. (1999). Learning in urban blight: school climate and its effect on the school performance of urban, minority, low-income children. School Psychology Review, $28,365-377$.

Freiberg, H. J., \& Stein, T. A. (1999). Measuring, improving and sustaining healthy learning environments. In H. J. Freiberg (Ed.), School climate: Measuring, improving and sustaining healthy learning environments (pp.11-29). Falmer Press.

George, D., \& Mallery, M. (2010). SPSS for windows step by step: a simple guide and reference, 17.0 update (10th ed.). Pearson.

Gibson, S., \& Dembo, M. (1984). Teacher efficacy: A construct validation. Journal of Educational Psychology, 76, 569-582. https://doi.org/10.1037/0022-0663.76.4.569

Hattie, J. (2003). Teachers make a difference: What is the research evidence? Melbourne, Australia: Australian Council for Educational Research. Retrieved January 25, 2020, from http://acer.edu.au

Hoy, W. K., \& Woolfolk, A. E. (1993). Teachers' sense of efficacy and the organizational health of schools. Elementary School Journal, 93, 355-372. https://doi.org/10.1086/461729

Hu, L. T., \& Bentler, P. M. (1999). Cutoff criteria for fit indexes in covariance structure analysis: Conventional criteria versus new alternatives. Structural Equation Modeling: A $\quad$ Multidisciplinary Journal, $\quad 6(1), \quad$ 1-55. https://doi.org/10.1080/10705519909540118 
IMF. (2021). World economic outlook (International Monetary Fund). International Monetary Fund.

Ingersoll, R. M. (2001). Teacher turnover and teacher shortages: An organizational analysis. American Educational Research Journal, 38(3), 499-534. https://doi.org/10.3102/00028312038003499

Jackson, D. L., Gillaspy, J. A., \& Purc-Stephenson, R. (2009). Reporting practices in confirmatory factor analysis: An overview and some recommendations. Psychological Methods, 14, 6-23. https://doi.org/10.1037/a0014694

Johnson, B., Stevens, J. J., \& Zvoch, K. (2007). Teachers' perceptions of school climate: A validity study of scores from the revised school level environment questionnaire. Educational and Psychological Measurement, 67(5), 833-844. https://doi.org/10.1177/0013164406299102

Judge, T. A., Thoresen, C. J., Bono, J. E., \& Patton, G. K. (2001). The job satisfactionjob performance relationship: A qualitative and quantitative review. Psychological Bulletin, 127, 376-407. https://doi.org/10.1037/0033-2909.127.3.376

Kalkan, F. (2020). Öğretmenlerin öz yeterlik inançları ve iş doyumu düzeyleri arasındaki ilişki: Bir meta analiz çalışması. Ĕgitim ve Bilim, 45(204), 317-343. http://dx.doi.org/10.15390/EB.2020.8549

Karagöz, Y. (2016). SPSS ve AMOS 23 uygulamal istatistiksel analizler. Nobel Akademi Yayınları.

Katsantonis, I. G. (2020). Investigation of the impact of school climate and teachers' self-efficacy on job satisfaction: A cross-cultural approach. Eur. J. Investig. Health Psychol. Educ., 10, 119-133. https://doi.org/10.3390/ejihpe10010011

Klassen, R. M., Usher, E. L., \& Bong, M. (2010). Teachers' collective efficacy, job satisfaction, and job stress in cross-cultural context. The Journal of Experimental Education, 78(4), 464-486. https://doi.org/10.1080/00220970903292975.

Kline, R.B. (2011). Principles and practice of structural equation modeling. Guilford Press.

Köksal, H. K. (2019). Okul psikolojik danışmanlarının özel eğitim öz yeterlik algıları ile iş doyumları arasındaki ilişki: Mersin ili örneği [Unpublished master's thesis]. Çağ Üniversitesi Sosyal Bilimler Enstitüsü.

Lee, M., \& Louis, K. S. (2019). Mapping a strong school culture and linking it to sustainable school improvement. Teaching and Teacher Education, 81, 84-96. https://doi.org/10.1016/j.tate.2019.02.001

Lee, V. E., Dedrick, R. F., \& Smith, J. B. (1991). The effect of the social organization of schools on teachers' efficacy and satisfaction. Sociology of Education, 64(3),190-208. https://doi.org/10.2307/2112851

Locke, E. A. (1976). The nature and causes of job satisfaction. In M. D. Dunnette (Ed.), Handbook of industrial and organizational psychology (pp. 1297-1343). Rand McNally.

Malinen, O. P., \& Savolainen, H. (2016). The effect of perceived school climate and teacher efficacy in behavior management on job satisfaction and burnout: A longitudinal study. Teaching and Teacher Education, 60, 144-152. https://doi.org/10.1016/j.tate.2016.08.012 
McConnell, J. R. (2017). A model for understanding teachers' intentions to remain in STEM education. International Journal of STEM Education, 4(1), 7. https://doi.org/10.1186/s40594-017-0061-8

Mert, A., \& Özdemir, G. (2019). Öğretmenlerin psikolojik okul iklimi algıları ile iş doyumu düzeyleri arasındaki ilişkinin incelenmesi. Insan ve Toplum Bilimleri Araştırmaları Dergisi, 8(1), 91-109.

Mitchell, M. M., Bradshaw, C. P., \& Leaf, P. J. (2010). Student and teacher perceptions of school climate: A multilevel exploration of patterns of discrepancy. Journal of school Health, 80(6), 271-279. https://doi.org/10.1111/j.1746-1561.2010.00501.x

Muijs, R. D., \& Rejnolds, D. (2001). Teachers' beliefs and behaviors: What really matters. Journal of Classroom Interaction, 37, 3-15.

OECD. (2014). TALIS 2013 results: an international perspective on teaching and learning. OECD Publishing.

OECD. (2019). TALIS 2018 technical report. OECD Publishing.

Podell, D., \& Soodak, L. (1993). Teacher efficacy and bias in special education referrals. Journal of Educational Research, 86, 247-253. https://doi.org/10.1080/00220671.1993.9941836

Polat, D. D. (2018). Öğretmenlerin yılmazlık düzeyleri ile iş doyumu, mesleki tükenmişlik, örgütsel bağlllık düzeyleri ve örgüt iklimi algılari arasındaki ilişkilerin incelenmesi [Unpublished master's thesis]. Sakarya Üniversitesi Eğitim Bilimleri Enstitüsü.

Raudenbush, S., Rowan, B., \& Cheong, Y. (1992). Contextual effects on the selfperceived efficacy of high school teachers. Sociology of Education, 65, 150-167. http://dx.doi.org/10.2307/2112680

Reyes, P., \& Shin, H. S. (1995). Teacher commitment and job satisfaction: A causal analysis. Journal of School Leadership, 5(1), 22-39. https://doi.org/10.1177/105268469500500102

Ross, J. A. (1998). The antecedents and consequences of teacher efficacy. In J. Brophy (Ed.), Advances in research on teaching, Vol. 7 (pp. 4974). JAI Press.

Ruma, V. R., Houchins, D., Jolivette, K., \& Benson, G. (2010). Efficacy beliefs of special educators: The relationships among collective efficacy, teacher selfefficacy, and job satisfaction. Teacher Education and Special Education, 33(3), 225-233. https://doi.org/10.1177/0888406409360129

Schaufeli, W. B., \& Salanova, M. (2007). Efficacy or inefficacy, that's the question: Burnout and work engagement, and their relationships with efficacy beliefs. Anxiety, Stress \& Coping: An International Journal, 20, 177-196.

Seyhan, H. G. (2015). Kimya öğretmenlerinin iş doyumları, öz-yeterlik algıları, örgütsel bağlılıkları ve iş streslerinin çeşitli değişkenler açısından incelenmesi. Turkish Journal of Education, 4(2), 41-60. https://doi.org/10.19128/turje.181114

Shahroom, A. A., \& Hussin, N. (2018). Industrial Revolution 4.0 and Education. International Journal of Academic Research in Business and Social Sciences, 8(9), 314-319. http://dx.doi.org/10.6007/IJARBSS/v8-i9/4593 
Skaalvik, E. M., \& Skaalvik, S. (2009). Does school context matter? relations with teacher burnout and job satisfaction. Teaching and Teacher Education, 25(3), 518524. https://doi.org/10.1016/j.tate.2008.12.006

Skaalvik, E. M., \& Skaalvik, S. (2010). Teacher self-efficacy and teacher burnout: A study of relations. Teaching and Teacher Education, 26, 1059-1069. https://doi.org/10.1016/j.tate.2009.11.001

Skaalvik, E. M., \& Skaalvik, S. (2011). Teacher job satisfaction and motivation to leave the teaching profession: Relations with school context, feeling of belonging, and emotional exhaustion. Teaching and Teacher Education, 27, 1029-1038. https://doi.org/10.1016/j.tate.2011.04.001

Skaalvik, E. M., \& Skaalvik, S. (2014). Teacher self-efficacy and perceived autonomy: relations with teacher engagement, job satisfaction, and emotional exhaustion. $\begin{array}{lll}\text { Psychological } & \text { Reports, }\end{array}$ http://dx.doi.org/10.2466/14.02.PR0.114k14w0

Skaalvik, E. M., \& Skaalvik, S. (2015). Job satisfaction, stress and coping strategies in the teaching pofession-what do teachers say? International Education Studies, 8(3), 181-192. http://dx.doi.org/10.5539/ies.v8n3p181

Soodak, L. C., \& Podell, D. M. (1993). Teacher efficacy and student problem as factors in special education referral. The Journal of Special Education, 27(1), 66-81. https://doi.org/10.1177/002246699302700105

Tabachnick, B., \& Fidel, L. (2001). Using multivariate statistics. Pearson.

Tanrı̈ğen, Z. M. (2018). The possible effects of 4th industrial revolution on Turkish educational system. Eurasian Journal of Educational Research, 77(2018), 163-184.

Telef, B. B. (2011). Öğretmenlerin öz-yeterlikleri, iş doyumları, yaşam doyumları ve tükenmişliklerinin incelenmesi. İlkögretim Online, 10(1), 91-108.

Thapa, A., Cohen, J., Guffey, S., \& Higgins-D’Alessandro, A. (2013). A review of school climate research. Review of Educational Research, 83(3), 357-385. https://doi.org/10.3102/0034654313483907

Tschannen-Moran, M., Woolfolk Hoy, A., \& Hoy, W. K. (1998). Teacher efficacy: Its meaning and measure. Review of Educational Research, 68, 202-248. https://doi.org/10.3102/00346543068002202

Turcan, H. G. (2011). Illköğretim okulu öğretmenlerinin özyeterlik alglları ile iş doyumları arasındaki ilişkinin incelenmesi [Unpublished master's thesis]. Selçuk Üniversitesi, Eğitim Bilimleri Enstitüsü.

UNESCO. (2021a, February 23). Global monitoring of school closures caused by COVID-19. Retrieved from https://en.unesco.org/covid19/educationresponse

UNESCO. (2021b, May 31). Global monitoring of school closures caused by COVID19. Retrieved from https://en.unesco.org/covid19/educationresponse

UNESCO-UIS. (2012). International Standard Classification of Education (ISCED) 2011, UNESCO Institute for http://uis.unesco.org/sites/default/files/documents/internationalstandardclassification-ofeducation-isced-2011-en.pdf 
Van Beurden, J., Van Veldhoven, M., Nijendijk, K., \& Van De Voorde, K. (2017). Teachers' remaining career opportunities: the role of value fit and school climate. Teaching and Teacher Education, 68, 143-150. https://doi.org/10.1016/j.tate.2017.09.002

Veldman, I., van Tartwijk, J., Brekelmans, M., \& Wubbels, T. (2013). Job satisfaction and teacher student relationships across the teaching career: Four case studies. Teaching and Teacher Education, 32, 55-65. https://doi.org/10.1016/j.tate.2013.01.005

You, S., Kim, A. Y., \& Lim, S. A. (2017). Job satisfaction among secondary teachers in Korea: effects of teachers' sense of efficacy and school culture. Educational Management Administration \& Leadership, 45(2), 284-297. https://doi.org/10.1177/1741143215587311

Yuan, K. H., Bentler, P. M., \& Zhang, W. (2005). The effect of skewness and kurtosis on mean and covariance structure analysis: The univariate case and its multivariate implication. Sociological Methods \& Research, 34(2), 240-258.

Zakariya, Y. F. (2020). Effects of school climate and teacher selfefficacy on job satisfaction of mostly STEM teachers: A structural multigroup invariance approach. International Journal of STEM Education, 7(10). https://doi.org/10.1186/s40594020-00209-4 


\section{Appendixes}

\section{Appendix 1}

T3DISC: Teachers' perceived disciplinary climate

TT3G41: How strongly do you agree or disagree with the following statements about this <target class>?

Response options: "Strongly disagree" (1), "Disagree" (2), "Agree" (3), "Strongly agree" (4).

TT3G41A When the lesson begins, I have to wait quite a long time for students to quieten down

TT3G41B ${ }^{*} \quad$ Students in this class take care to create a pleasant learning atmosphere

TT3G41C I lose quite a lot of time because of students interrupting the lesson

TT3G41D There is much disruptive noise in this classroom

T3STUD: Teacher-student relations

TT3G49: How strongly do you agree or disagree with the following statements about what happens in this school?

Response options: "Strongly disagree" (1), "Disagree" (2), "Agree" (3), "Strongly agree" (4).

TT3G49A Teachers and students usually get on well with each other.

TT3G49B Most teachers believe that the students' well-being is important.

TT3G49C Most teachers are interested in what students have to say.

TT3G49D If a student needs extra assistance, the school provides it.

T3STAKE: Participation among stakeholders, teachers

TT3G48: How strongly do you agree or disagree with these statements, as applied to this school?

Response options: "Strongly disagree" (1), "Disagree" (2), "Agree" (3), "Strongly agree" (4).

TT3G48A This school provides staff with opportunities to actively participate in school decisions.

TT3G48B This school provides parents or guardians with opportunities to actively participate in school decisions.

TT3G48C This school provides students with opportunities to actively participate in school decisions.

TT3G48D This school has a culture of shared responsibility for school issues.

TT3G48E There is a collaborative school culture which is characterised by mutual support.

* Item was reverse coded.

\section{Appendix 2}

\begin{tabular}{|c|c|}
\hline \multicolumn{2}{|r|}{ T3SELF: Teacher self-efficacy, composite } \\
\hline \multicolumn{2}{|c|}{ T3SECLS: Self-efficacy in classroom management (subscale) } \\
\hline \multicolumn{2}{|c|}{ TT3G34: In your teaching, to what extent can you do the following? } \\
\hline \multicolumn{2}{|c|}{ Response options: "Not at all" (1), "To some extent" (2), "Quite a bit" (3), "A lot" (4). } \\
\hline TT2G34D & Control disruptive behaviour in the classroom \\
\hline TT2G34F & Make my expectations about student behaviour clear \\
\hline TT2G34H & Get students to follow classroom rules \\
\hline TT2G34I & Calm a student who is disruptive or noisy \\
\hline \multicolumn{2}{|c|}{ T3SEINS: Self-efficacy in instruction (subscale) } \\
\hline \multicolumn{2}{|c|}{ TT3G34: In your teaching, to what extent can you do the following? } \\
\hline \multicolumn{2}{|c|}{ Response options: "Not at all" (1), "To some extent" (2), "Quite a bit" (3), "A lot" (4). } \\
\hline TT2G34C & Craft good questions for students \\
\hline TT2G34J & Use a variety of assessment strategies \\
\hline TT2G34K & Provide an alternative explanation, for example when students are confused \\
\hline TT2G34L & Vary instructional strategies in my classroom \\
\hline \multicolumn{2}{|c|}{ T3SEENG: Self-efficacy in student engagement (subscale) } \\
\hline \multicolumn{2}{|c|}{ TT3G34: In your teaching, to what extent can you do the following? } \\
\hline \multicolumn{2}{|c|}{ Response options: "Not at all" (1), "To some extent" (2), "Quite a bit" (3), "A lot" (4). } \\
\hline TT2G34A & Get students to believe they can do well in school work \\
\hline TT2G34B & Help students value learning \\
\hline TT2G34E & Motivate students who show low interest in school work \\
\hline TT2G34G & Help students think critically \\
\hline
\end{tabular}




\section{Appendix 3}

\section{T3JOBSA: Job satisfaction, composite}

T3JSENV: Job satisfaction with work environment (subscale)

\begin{tabular}{|c|c|}
\hline $\begin{array}{l}\text { TT3G53: We } \\
\text { following sta }\end{array}$ & $\begin{array}{l}\text { ike to know how you generally feel about your job. How strongly do you agree or disagree with the } \\
\text { ? }\end{array}$ \\
\hline Response 0 & Strongly disagree" (1), "Disagree" (2), "Agree" (3), "Strongly agree" (4). \\
\hline Tा3G53C* & I would like to change to another school if that were possible \\
\hline TT3G53E & I enjoy working at this school \\
\hline TT3G53G & I would recommend this school as a good place to work \\
\hline$\pi 3 G 53 \mathrm{~J}$ & All in all, I am satisfied with my job \\
\hline & T3JSPRO: Job satisfaction with profession (subscale) \\
\hline $\begin{array}{l}\text { TT3G53: We } \\
\text { following sta }\end{array}$ & $\begin{array}{l}\text { kke to know how you generally feel about your job. How strongly do you agree or disagree with the } \\
\text { ? }\end{array}$ \\
\hline Response 0 & Strongly disagree" (1), "Disagree" (2), "Agree" (3), "Strongly agree" (4). \\
\hline TT3G53A & The advantages of being a teacher clearly outweigh the disadvantages \\
\hline TT3G53B & If I could decide again, I would still choose to work as a teacher. \\
\hline TT3G53D* & I regret that I decided to become a teacher \\
\hline TT3G53F* & I wonder whether it would have been better to choose another profession \\
\hline & T3SATAT: Satisfaction with target class autonomy \\
\hline $\begin{array}{l}\text { TT3G40: Ho } \\
\text { in this } 4 \text { targe }\end{array}$ & $\begin{array}{l}\text { Iy do you agree or disagree that you have control over the following areas of your planning and teaching } \\
\text { ? }\end{array}$ \\
\hline Response 0 & Strongly disagree" (1), "Disagree" (2), "Agree" (3), "Strongly agree" (4). \\
\hline TT3G40A & Determining course content \\
\hline Tा3G40B & Selecting teaching methods \\
\hline ТТЗG40C & Assessing students' learning \\
\hline TT3G40D & Disciplining students \\
\hline Tा3G40E & Determining the amount of homework to be assigned \\
\hline
\end{tabular}

* Items were reverse coded. 